\title{
PENINGKATAN MOTIVASI DAN HASIL BELAJAR PECAHAN DENGAN MENGGUNAKAN PENDEKATAN KOOPERATIF TIPE TGT DI KELAS V SDN 04 KAYU MANANG
}

\author{
Saidi \\ saidijatim@gmail.com \\ Sekolah Dasar Negeri 04 Kayu Manang
}

\begin{abstract}
The research was motivated by the low motivation and learning outcomes of mathematics in class V SDN 04 Kayu Manang Surian. The research objective is to increase motivation and learning outcomes of Mathematics by using the approach of cooperative type of TGT. This type of research is Classroom Action Research, which was carried out in 2 cycles in the second semester of 2015/2016 with the subject of teacher research and fifth grade students totaling 22 people. Research data were collected through observing student activities, learning motivation questionnaires and tests. The research findings show that the use of the TGT cooperative model approach can increase motivation and student learning outcomes in learning mathematics. Increased student motivation can be seen in the first cycle with a percentage of $20 \%$ of students expressed strongly agree, $51 \%$ of students agreed. Whereas in the second cycle, they got a score of 46\%, the students strongly agreed, 30\% of the students agreed. Improved student learning outcomes seen in cycle 1 with an average value of 68.55, in the second cycle to 7.32. Based on the findings of this study concluded that the approach model of learning cooperative tpe TGT can be used as an alternative to increase motivation and student learning outcomes in learning mathematics
\end{abstract}

Keywords: motivation, learning outcomes mathematics, team games tournament(TGT)

\section{ABSTRAK}

Penelitian dilatar belakangi oleh masih rendahnya motivasi dan hasil belajar matematika di kelas V SDN 04 Kayu Manang Surian. Tujuan penelitian adalah untuk meningkatkan motivasi dan hasil belajar Matematika dengan menggunakan pendekatan kooperatif tipe TGT. Jenis penelitian adalah Penelitian Tindakan Kelas (PTK) yang dilaksanakan sebanyak 2 siklus pada semester II 2015/2016 dengan subjek penelitian guru dan siswa kelas V yang berjumlah 22 orang. Data penelitian dikumpulkan melalui pengamatan aktivitaas siswa, angket motivasi belajar dan tes. Temuan penelitian menunjukkan bahwa penggunaan pendekatan model kooperatif tipe TGT dapat meningkatkan motivasi dan hasil belajar siswa pada pembelajaran Matematika. Peningkatan motivasi belajar siswa terlihat pada siklus I dengan persentase $20 \%$ siswa menyatakan sangat setuju, $51 \%$ siswa menyatakan setuju. Sedangkan pada siklus II memperoleh nilai dengan persentase $46 \%$ siswa menyatakan sangat setuju, $30 \%$ siswa menyatakan setuju. Peningkatan hasil belajar siswa terlihat pada siklus 1 dengan nilai rata-rata 68,55, pada siklus II menjadi 77,32. Berdasarkan temuan penelitian dapat disimpulkan bahwa pendekatan model pembelajaran kooperatif tpe TGT dapat digunakan sebagai salah satu alternatif untuk meningkatkan motivasi dan hasil belajar siswa pada pembelajaran Matematika.

Kata Kunci: motivasi, hasil belajar matematika, team games tournament(TGT)

\begin{tabular}{|c|c|c|}
\hline Submitted & Accepted & Published \\
\hline 3 September 2019 & 14 September 2019 & 21 September 2019 \\
\hline
\end{tabular}

\begin{tabular}{|l|l|l|}
\hline Citation & $:$ & $\begin{array}{r}\text { Saidi. (2019). Peningkatan Motivasi dan Hasil Belajar Pecahan dengan Menggunakan Pendekatan Kooperatif Tipe } \\
\text { TGT di Kelas V SDN 04 Kayu Manang. Jurnal PAJAR (Pendidikan dan Pengajaran), 3(5), 1052-1064. } \\
\text { DOI: http://dx.doi.org/10.33578/pjr.v3i5.7886. }\end{array}$ \\
\hline
\end{tabular}

*Copyright @ 2019Jurnal PAJAR (Pendidikan dan Pengajaran) Publish by PGSD FKIP Universitas Riau, Pekanbaru, Indonesia

\section{PENDAHULUAN}

Matematika sangat penting dikuasai oleh siswa karena hampir segala aspek kehidupan manusia membutuhkan matematika. Siswa memerlukan matematika untuk berhitung, menghitung panjang serta luas suatu benda, mengumpulkan, mengolah, menyajikan, menafsir data dan lain sebagainya. Menurut Karso (2008:1-
4) menyatakan "Matematika adalah ilmu deduktif, aksiomatik, formal, abstrak, hierarkis, bahasa simbol yang padat anti dan semacamnya sehingga para ahli matematika dapat mengembangkan sebuah sistem matematika." Depdiknas (2006:417) mata pelajaran matematika bertujuan agar siswa memiliki kemampuan: (1) memahami 
konsep matematika, menjelaskan keterkaitan antar konsep dan mengaplikasikan konsep atau algoritma, secara luwes, akurat, efisien, dan tepat dalam pemecahan masalah; (2) menggunakan penalaran pada pola dan sifat, melakukan manipulasi matematika dalam membuat generalisasi, menyusun bukti, atau menjelaskan gagasan dan pernyataan matematika, memecahkan masalah yang meliputi kemampuan memahami masalah, merancang model matematika, menyelesaikan model dan menafsirkan solusi yang diperoleh; (4) mengomunikasikan gagasan dengan simbol, tabel, diagram, atau media lain untuk memperjelas keadaan atau masalah; (5) memiliki sikap yang menghargaikegunaan matematika dalam kehidupan, yaitu memiliki rasa ingin tahu,perhatian,dan minat dalam mempelajari matematika, serta sikap ulet dan percaya diri dalam pemecahan masalah.

Berdasarkan tujuan pembelajaran matematika pada Deprmendiknas di atas siswa dituntut untuk menguasai konsep matematika, memahami permasalahan matematika, dan dapat menyelesaikan segala permasalahan matematika dengan ulet dan percaya diri. Meskipun matematika memiliki peranan penting dalam kehidupan sehari-hari, banyak kalangan termasuk para siswa di sekolah yang tidak menyukai pelajaran matematika, sehingga akibatnya para siswa kurang termotivasi dan bersungguh-sungguh dan dalam mempelajari matematika. Hal ini disebabkan oleh beberapa faktor, diantaranya adalah kesulitan siswa dalam memahami konsepkonsep matematika, ketidakmauan mereka untuk bertanya tentang materi yang belum dipahami karena takut atau malu berbuat kekeliruan atau mungkin takut dianggap bodoh oleh guru dan teman-temannya.

Hal ini dirasakan langsung oleh peneliti pada saat melaksanakan pembelajaran matematika di Kelas V SD Negeri 04 Kayu Manang Surian. Menurut pengamatan Peneliti siswa kurang termotivasi dan bersungguh-sungguhdalam mempelajari matematika, tidak tekun mengerjakan tugas matematika, sehinga banyak tugas matematika yang tidak diselesaikan secara sempurna, cepat putus asa atau tidak ulet mengerjakan tugas yang diberikan baik tugas secara pribadi maupun tugas kelompok, tidak yakin dengan tugas matematika yang dibuatnya, tidak senang mencari dan memecahkan masalah yang ada pada pembelajaran matematika. Akibatnya hasil belajar matematika di kelas V SD Negeri 04 Kayu Manang Surian masih jauh dari yang diharapkan. Dari hasil ujian semester yang telah dilaksanakan siswa hanya sebagian kecil siswa yang memperoleh nilai di atas Keteria Ketuntasan Minimal (KKM). Sebaliknya sebagian besar siswa memperoleh nilai dibawah KKM yang telah di tetapkan oleh sekolah yaitu 75 hal ini sesuai dengan KKM dalam kurikulum KTSP. Depdiknas, (2006:19) "Kriteria ketuntasan Minimal adalah batas minimal pencapaian kompetensi pada aspek penilaian mata pelajaran yang harus dikuasai oleh siswa yang idealnya adalah $75 \%$ ". Hal tersebut dapat dilihat dari nilai ujian semester II hanya 8 dari 22 orang siswa atau $36.4 \%$ yang mencapai ketuntasan dan 14 siswa atau $63.6 \%$ siswa yang tidak tuntas. Sementara itu, berdasarkan hasil ujian MID semester I pada pada tahun ajaran 2015-2016, rata-rata yang diperoleh siswa hanya mencapai 51,19 dari 28 siswa yang mengikuti ujian.

Selain itu dari beberapa faktor di atas penyebab dari kurangnya hasil belajar siswa adalah kurang efektifnya strategi pembelajaran yang diterapkan guru. Hal ini bisa dilihat dari proses pembelajaran yang dilaksanakan guru, dimana guru lebih banyak bercerita di depan kelas, guru sering menjadi juru selamat dalam permasalahan yang ditemui oleh siswa selama proses pembelajaran sehinggga siswa kurang memiliki kesempatan untuk menggali kemampuan yang mereka miliki untuk menemukan sendiri konsep-konsep pembelajaran matematika.

Berdasarkan uraian di atas rendahnya motivasi dan hasil belajar siswa disebabkan oleh kurang efektifnya pendekatan dan metode pembelajaran yang digunakan oleh guru. Akibatnya siswa kurang termotivasi dan bersungguh-sungguh dalam pembelajaran matematika sehingga siswa kesulitan dalam memahami pembelajaran matematika.Salah satu pendekatan yang dapat digunakan guru dalam menghadapi permasalahan di atas adalah menggunakan model pembelajaran kooperatif, karena pembelajaran Kooperatif lebih 
menekankan interaksi antar siswa. Karena siswa akan melakukan komunikasi aktif dengan sesama temannya. Dengan komunikasi tersebut diharapkan siswa dapat menguasai materi pelajaran dengan mudah. Menurut Sulaiman (dalam Wahyuni, 2001:2) "Siswa lebih mudah memahami penjelasan dari temannya dibanding penjelasan dari guru karena taraf pengetahuan serta pemikiran mereka lebih sejalan dan sepadan".

Salah satu upaya untuk meningkatkan motivasi dan hasil belajar siswa dengan mengembangkan strategi pembelajaran kooperatif. Usman (2008:21) berpendapat bahwa "dalam menciptakan kondisi belajar mengajar yang efektif setidaknya ada lima variabel yang menentukankeberhasilanbelajar siswa, yaitu melibatkan siswa secara aktif, menarik minat dan perhatian siswa, membangkitkan motivasi siswa, memperhatikan kemampuan siswa dan menggunakan alat peraga yang tepat". Masalah utama dalam penelitian ini adalah bagaimana proses pembelajaran dapat membuat siswa aktif dan termotivasi dalam kegiatan belajar mengajar

\section{KAJIAN TEORETIS}

\section{Motivasi Belajar}

Menurut Makmun (2007: 37) "motivasi merupakan (1) suatu kekuatan (power) atau tenaga (forces) atau daya (energy); atau (2) suatu keadaan yang kompleks (a complex state) dan kesiapsediaan (preparatory set) dalam diri individu (organisme) untuk bergerak (to move, motion, motive) ke arah tujuan tertentu, baik disadari maupun tidak disadari”. Menurut Uno (2009:3) "motivasi merupakan dorongan yang terdapat dalam diri seseorang untuk berusaha mengadakan perubahan tingkah laku yang lebih baik dalam memenuhi kebutuhannya". Suryabrata (2011:70) mengemukakan "motif adalah keadaan dalam pribadi orang yang mendorong individu untuk melakukan aktiviatas-aktivitas tertentu guna mencapai suatu tujuan". Sedangkan Sheriff \& Sheriff dalam (Alex Sobour, 2003:265) menyebutkan "motif sebagai suatu istilah genetic yang meliputi semua faktor internal yang mengarah pada berbagai jenis perilaku yang bertujuan, semua pengaruh internal, seperti dengan menggunakan metode pembelajaran yang tepat dan menarik, sehingga prestasi belajar siswa dapat meningkat.

Hal mendasar yang menjadi alasan pemilihan metode ini karena model pembelajaran kooperatif tipe TGT (Teams Games Tournament) salah satu tipe atau model pembelajaran kooperatif yang mudah diterapkan, melibatkan aktivitas seluruh siswa tanpa harus ada perbedaan status, melibatkan peran siswa sebagai tutor sebaya dan mengandung unsur permainan dan penguatan. Aktivitas belajar dengan permainan yang dirancang dalam pembelajaran kooperatif model TGT memungkinkan siswa dapat belajar lebih rileks disamping menumbuhkan tanggung jawab, kerjasama, persaingan sehat dan keterlibatan belajar.

Berdasarkan uraian pada latar belakang di atas maka tujuan dari penelitian ini adalah untuk meningkatan motivasi dan hasil belajar pecahan dengan menggunakan pendekatan kooperatif tipe TGT di kelas V SDN 04 Kayu Manang Surian Kabupaten Solok."

kebutuhan (need) yang berasal dari fungsi-fungsi organisme, dorongan dan keinginan, aspirasi dan selera sosial, yang bersumber dari fungsi-fungsi tersebut".

Menurut Mc. Donald (dalam Sardiman, 2010:73) "motivasi adalah perubahan energi dalam diri seseorang yang ditandai dengan munculnya "feeling" dan didahului dengan tanggapan terhadap adanya tujuan". Menurut Purwanto (2007:60) "motif adalah suatu pernyataan yang kompleks di dalam suatu organisme yang mengarahkan tingkah laku/ perbuatan ke suatu tujuan atau perangsang".

Berdasarkan uraian di atas, maka dapat diambil pengertian motivasi adalah suatu kekuatan atau dorongan dalam diri individu membuat individu tersebut bergerak, bertindak untuk memenuhi kebutuhan dan mencapai tujuannya. 


\section{Model TGT}

Menurut Slavin (dalam Narulita Yusron, 2011:163-168) "model pembelajaran kooperatif tipe Tipe Teams Games Tournaments (TGT) menggunakan permainan akademik. Dalam tournament itu, siswa bertanding mewakili timnya dengan anggota tim lain yang setara kemampuan akademik berdasarkan kinerja sebelumnya. Komponen-komponen dalam Tipe Teams Games Tournaments (TGT) yang diungkapkan Slavin meliputi prestasi kelas, belajar tim, dan turnamen berupa permainan".

Pembelajaran model TGT adalah suatu meodel pembelajaran yang didahului dengan penyajian materi pembelajaran oleh guru dan diakhiri dengan memberikan sejumlah pertanyaan kepada siswa. Setelah itu, siswa pindah kekelompok masing-masing untuk mendiskusikan dan menyelesaikan pertanyaan-pertanyaan atau masalah-masalah yang diberikan oleh guru".

Rusman (2011:224) "TGT merupakan salah satu tipe model pembelajaran kooperatif yang menempatkan siswa dalam kelompok-kelompok belajar yang memiliki kemampuan, jenis kelamin, dan suku atau ras yang berbeda".

Berdasarkan pendapat ahli di atas disimpulkan bahwa Model Teams Games Tournaments adalah suatu model pembelajaran yang digunakan dalam proses belajar mengajar yang diawali dengan pemberian materi kepada siswa dan menempatkan siswa dalam kelompokkelompok kecil yang bersifat heterogen dan setiap siswa berperan aktif dalam pembelajaran yang dikemas dalam bentuk turnamen akademik untuk memperoleh skor.

\section{Langkah-langkah Model TGT}

Menurut Slavin (dalam Narulita Yusron 2010:170), langkah-langkah TGT, terdiri dari pengajaran, belajar tim, turnamen, dan rekognisi tim.

1) Pengajaran

Pada langkah pengajaran, guru menyampaikan materi pelajaran dengan cara presentasi di dalam kelas. Presentasi tersebut mencakup pembukaan, pengembangan, dan pengarahan praktis tiap komponen dari keseluruhan materi pelajaran. Pada langkah ini juga digunakan guru untuk menjelaskan teknik pelaksanaan pembelajaran dengan menerapkan TGT.

2) Belajar Tim

Selama belajar dalam tim, tugas para anggota tim yaitu menguasai materi yang telah disampaikan guru dalam presentasi kelas dan membantu anggota lainnya untuk menguasai materi tersebut. Setiap tim mempunyai lembar kegiatan yang dapat mereka gunakan untuk melatih kemampuan selama proses pengajaran, serta untuk menilai diri mereka sendiri dan teman sekelasnya. Lembar kegiatan berupa pertanyaan-pertanyaan mengenai materi pelajaran yang telah disampaikan guru.

3) Game (Permainan)

Game atau permainan terdiri atas pertanyaan-pertanyaan yang dirancang untuk menguji pengetahuan siswa yang diperoleh dari presentasi kelas dan pelaksanaan kerja tim. Siswa dalam kegiatan ini tidak diperkenankan bekerjasama

4) Turnamen

Sebelum pelaksanaan turnamen, guru menyediakan lembar pemainan, lembar jawaban, lembar skor permainan, dan satu boks kartu bernomor untuk setiap meja turnamen. Sebelum memulai turnamen, siswa yang memiliki kemampuan setara duduk bersama dalam satu meja turnamen. 


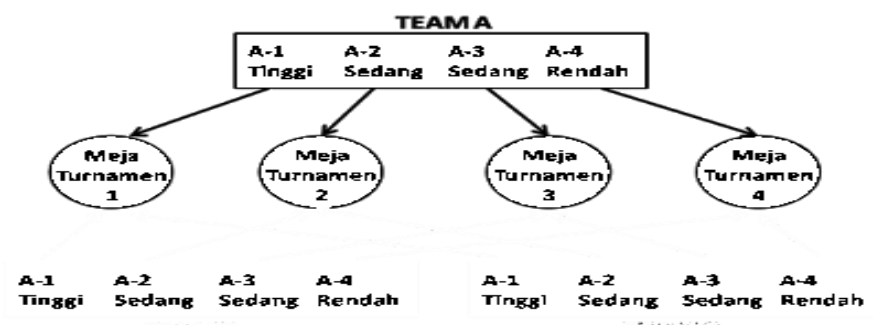

Penempatan siswa pada meja turnamen menurut Slavin (2010: 168)

\section{Gambar 1. Penempatan Meja Turnamen}

Untuk memulai turnamen, para siswa dalam setiap meja turnamen menarik kartu bernomor untuk menentukan pembaca yang pertama, yaitu siswa yang mendapat nomor tertinggi. Pembaca mengocok kartu bernomor dan mengambil kartu yang paling atas, kemudian membaca dan menjawab pertanyaan sesuai dengan nomor pada kartu yang diambil. Setelah pembaca memberikan jawaban, penantang I mempunyai pilihan untuk menantang dan memberikan jawaban yang berbeda atau melewatinya. Begitu pula dengan penantang II, jika ia mempunyai jawaban yang berbeda dengan pembaca dan penantang I, maka penantang II atau penantang terakhir boleh menantang atau memilih untuk melewatinya.

Setelah semua peserta memberikan jawaban atau melewati pertanyaan, penantang terakhir memeriksa dan membacakan jawaban yang benar. Siswa yang memberikan jawaban dengan benar akan menyimpan kartunya. Jika jawaban yang diberikan pembaca salah, maka pembaca tidak mendapatkan sanksi. Namun, jika jawaban yang diberikan penantang salah, maka penantang mendapatkan sanksi, yaitu harus mengembalikan kartu kemenangannya. Untuk putaran berikutnya, semua peserta bergerak satu posisi, yaitu penantang I menjadi pembaca, penantang II menjadi penantang I, dan pembaca menjadi penantang II. Setelah turnamen selesai, siswa mencatat nomor yang telah dimenangkan pada lembar skor permainan dan menambahkan poin yang diperoleh pada setiap game.

5) Rekognisi Tim

Setelah diperoleh hasil, kemudian dihitung skor peningkatan individu berdasarkan selisih perolehan skor kuis terdahulu (skor dasar) dengan skor kuis terakhir. Berdasarkan skor peningkatan individu dihitung poin perkembangan dengan menggunakan pedoman yang disusn oleh Slavin (dalam Asma, 2008:113;114) seperti dalam tabel berikut:

Tabel 1. Skor Peningkatan Individu

\begin{tabular}{lc}
\hline \multicolumn{1}{c}{ Skor Kuis } & $\begin{array}{c}\text { Poin } \\
\text { Perkembangan }\end{array}$ \\
\hline Lebih dari sepuluh poin di bawah skor dasar & 5 Poin \\
\hline 10 sampai 1 poin di bawah skor dasar & 10 Poin \\
\hline Skor dasar, sampai sepuluh poin di atas skor dasar & 20 Poin \\
\hline Lebih dari 10 poin di atas skor dasar & 30 Poin \\
\hline Pekerjaan sempurna (tanpa memperhatikan skor dasar) & 30 Poin \\
\hline
\end{tabular}

\section{METODE PENELITIAN}

Jenis penelitian dalam penelitian ini adalah Penelitian Tindakan Kelas (PTK).Menurut Kunandar (2008:46) "penelitian tindakan kelas adalah bentuk kegiatan refleksi diri yang dilakukan oleh para pelaku pendidikan untuk 
memperbaiki rasionalitas dan keadilan tentang praktik-praktik kependidikan".

Subjek penelitian ini adalah peserta didik kelas V SDN 04 Kayu Manang Surian Kecamatan Pantai Cermin Kabupaten Solok berjumlah 22 orang.

Sesuai dengan rumusan masalah hasil studi pendahuluan, Peneliti membuat rencana tindakan yang akan dilakukan. Tindakan berupa pembelajaran pecahan dengan menggunakan pendekatan $T G T$ kegiatan itu dimulai dengan : 1) menentukan jadwal penelitian; 2) mempersiapkan rancangan pembelajaran pendekatan TGT; 3) mempersiapkan intrumen penelitian berupa lembar pengamatan aktivitas siswa dan angket motivasi.

Data yang diperoleh dalam penelitian dianalisis dengan menggunakan model analisis data kualitatif dan kuantitatif. Analisis data kualitatif yaitu berhubungan dengan hasil pengamatan observasi dan pencatatan lapangan. Analisis kuantitatif yaitu yang berkaitan dengan hasil belajar/tes yang diberikan pada setiap akhir siklus untuk mengetahui peningkatan aktivitas dan hasil belajar peserta didik.

Miles (dalam Rochiati, 2007:18) "analisis data kualitatif dimulai dengan menelaah sejak pengumpulan data sampai seluruh data terkumpul, data tersebut direduksi berdasarkan masalah yang diteliti, diikuti penyajian data dan terakhir penyimpulan atau verifikasi. Tahap analisis yang demikian dilakukan berulang-ulang begitu data selesai dikumpulkan pada setiap tahap pengumpulan data dalam setiap tindakan". Tahap analisis tersebut diuraikan sebagai berikut:

1. Menelaah data yang terkumpul baik melalui observasi, pencatatan dengan melakukan proses transkirpsi hasil pengamatan, penelitian dan pemilihan data. Seperti mengelompokan pada siklus 1, dan seterusnya. Menelaah data dilaksanakan sejak awal data dikumpulkan.

2. Reduksi data meliputi pengkategorian dan pengklasifikasian. Semua data yang telah terkumpul diseleksi dan dikelompokkelompokkan sesuai fokus penelitian. Data yang telah dipisah-pisahkan tersebut lalu diseleksi mana yang relevan dan mana yang tidak relevan. Data yang relevan dianalisis dan yang tidak relevan dibuang.
3. Menyajikan data dilakukan dengan cara mengorganisasikan informasi yang telah direduksi. Data tersebut mula-mula disajikan terpisah, tetapi setelah tindakan terakhir direduksi, keseluruhan data tindakan dirangkum dan disajikan secara terpadu sehingga diperoleh sajian data tunggal berdasarkan fokus pembelajaran matematika di kelas V SD dengan menggunakan pendekatan koperatif tipe team games tournament .

Data yang dianalisis dalam penelitian ini diambil dari pengamatan aktivitas guru, pengamatan aktivitas siswa, lembar penilaian angket motivasi belajar siswa, dan hasil belajar.

1. Penilaian Motivasi belajar

Penilaian motivasi belajar dalam penelitian ini dilakukan dengan menggunakan angket motivasi belajar, angket motivasi yang digunakan terdiri dari enam indikator yang dibagi menjadi dua faktor yakni faktor instrinsik dan faktor ekstrinsik. Faktor instrinsik meliputi :

a. Adanya hasrat dan keinginan berhasil terdiri dari empat penyataan, (1) saya senang mengerjakan PR Matematika, (2) pelajaran Matematika manfaatnya buat saya, (3) saya berusaha mempelajari buku-buku matematika selain yang diwajibkan guru agar wawasan bertambah, (4) saya berusaha mempelajari buku-buku matematika selain yang diwajibkan guru agar wawasan bertambah.

b. Adanya dorongan dan kebutuhan dalam belajar terdiri dari lima pernyataan, (1) mampu mengerjakan soal Matematika yang sulit membuat saya bangga, (2) saya tetap mengerjakan soal Matematika meskipun sulit, (3) saya yakin dapat menyelesaikan soal matematika dengan benar, (4) saya tetap belajar Matematika walaupun nilai ulangan Matematika jelek, (5) saya ingin belajar Matematika.

c. Adanya harapan dan cita-cita masa depan terdiri dari tiga pernyataan, (1) saya senang jika nilai ulangan matematika bagus, (2) pelajaran matematika manfaatnya buat saya, (3) saya berani bertanya jika ada pelajaran Matematika yang belum saya mengerti.

Adapun faktor ekstrinsik terdiri dari :

a. Adanya penghargaan dalam belajar terdiri dari dua pernyataan, (1) mendapatkan penghargaan 
dalam belajar sangat penting untuk saya, (2) penghargaan dari guru membuat saya bersemangat untuk belajar matematika.

b. Adanya kegiatan yang menarik dalam belajar terdiri dari tiga pernyataan, (1) gambar yang berwarna-warni membuat saya senang, (2) belajar dengan gambar membuat saya lebih focus, (3) bertukar pikiran dengan teman sebangku sangat menyenangkan.

c. Adanya lingkungan belajar yang kondusif terdiri dari dua pernyataan, (1) saya lebih senang berpikir sendiri daripada mempercayai jawaban teman walaupun dia lebih pandai dari saya, (2) bertukar pikiran dengan teman dalam menyelesaikan soal Matematika menghilangkan rasa cemas saya terhadap pelajaran matematika.

Angket motivasi belajar digunakan untuk melihat peningkatan motivasi dan membandingkan rata-rata persentase dari setiap indikator-indikator motivasi belajar yang telah diberikan pada tiap akhir siklus. Penilaian hasil motivasi belajar siswa pada penelitian ini akan difokuskan pada pernyataan sangat setuju dan setuju dari jumlah pernyataan yang diisi oleh seluruh siswa di kelas V SDN 04 Kayu Manang Surian.

Persentase nilai motivasi belajar dicari dengan menggunakan rumus:

$\%=\frac{n}{N} \times 100 \%$

\section{HASIL DAN PEMBAHASAN}

Penelitian tindakan kelas dilaksanakan sebanyak 2 siklus masing-masing siklus dua kali pertemuan. Siklus I dilaksanakan tanggal 29 dan 31 Maret 2016, dan siklus II dilaksanakan tanggal 5 dan 7 April 2016

Pelaksanaan tindakan kelas ini, peneliti dibantu oleh guru kepala sekolah dan guru kelas V SDN 04 Kayu Manag Surian yang bertindak sebagai observer.
Keterangan :

$\%=$ Tingkat porsentase yang berhasil dicapai

$\mathrm{n} \quad=$ Nilai yang diperoleh

$\mathrm{N} \quad=$ Nilai total

2. Hasil Belajar

Ketuntasan individu dengan rumus

NI $=\frac{T}{S M} \times 100 \%($ Depdiknas, 2004)

Keterangan :

NI $=$ Ketuntasan individu

$\mathrm{T}=$ Skor yang diperoleh peserta didik

$\mathrm{N}=$ Skor maksimum dari tes

Ketuntasan individu tercapai apabila peserta didik mendapat skor lebih besar/sama dengan KKM yang ditetapkan.

Ketuntasan klasikal dapat dihitung dengan menggunakan rumus :

$\mathrm{NI}=\frac{T}{S M} \times 100 \%($ depdiknas, 2006$)$

Keterangan :

NI $=$ Ketuntasan klasikal

$\mathrm{T} \quad=$ Jumlah peserta didik yang tuntas

$\mathrm{N} \quad=$ Jumlah seluruh peserta didik

Ketuntasan klasikal tercapai apabila $70 \%$ peserta didik mendapat skor lebih besar/sama dengan KKM yang ditetapkan.

\section{Penilaian Motivasi Belajar Siswa}

Berdasarkan angket motivasi yang telah diberikan setelah menerapkan model kooperatif tipe TGT dalam pembelajaran Matematika motivasi siswa dalam mengikuti pelajaran mengalami peningkatan pada tiap siklusnya. Hal ini dapat dilihat dari porsentase penilaian motivasi belajar Siswa Siklus I dan II pada gambar dibawah ini: 


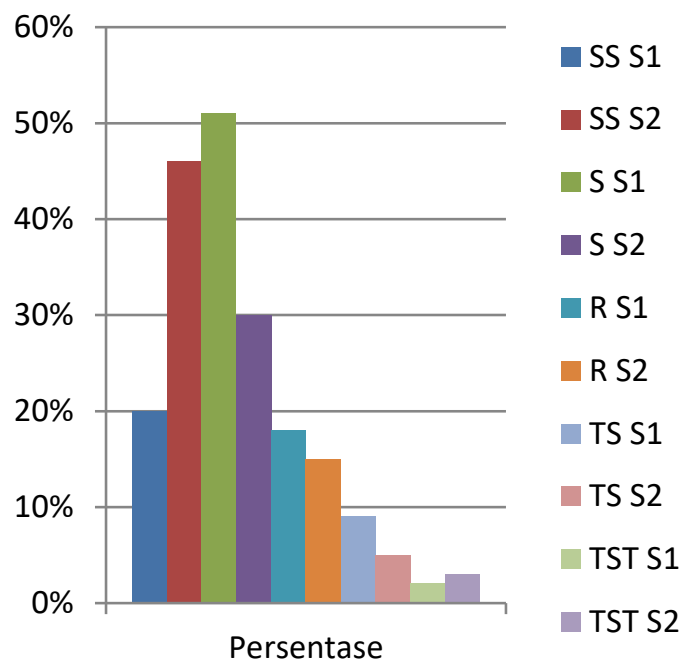

Gambar 2. Diagram Persentase Hasil Penilaian Motivasi Belajar Siswa Siklus I dan II

Berdasarkan gambar diagram di atas dapat dilihat bahwa persentase siswa yang menyatakan sanagt setuju dengan pernyataanpernyataan yang telah peneliti berikan melalui angket motivasi yaitu: pada siklus I sebanyak $20 \%$ siswa menyatakan sangat setuju dan $51 \%$ menyatakan setuju. Sedangkan pada siklus II sebanyak $46 \%$ siswa menyatakan sangat setuju dan $30 \%$ siswa menyatakan setuju. Peningkatan motivasi siswa pada tiap siklus terjadi karena adanya perbaikan dan pelaksanaan dalam memotivasi siswa seperti membangkitkan minat siswa dalam belajar, memberikan semangat dalam proses belajar, memberikan penghargaan dan pujian dalam belajar, menggunakan media belajar yang menarik dan menciptakan lingkungan kelas yang bersih, rapi, nyaman, dan menyenangkan dalam belajar.

Membangkitkan minat siswa dalam belajar perlu dilakukan karena proses belajar akan berjalan lancar kalau disertai dengan minat dan keinginan yang kuat. Hal ini sesuai dengan pendapat Sardiman (2011:98) "Motivasi muncul karena adanya kebutuhan, begitu juga minat sehingga tepatlah kalau minat merupakan alat motivasi yang pokok. Proses belajar akan berjalan lancaar kalau disertai minat". Agar siswa memiliki minat dalam belajar salah satu yang peneliti lakukan adalah dengan mengkondisikan kelas dengan baik, seperti: mengecek kesiapan siswa sebelum belajar secara fisik dan mental karena kesiapan dan mental akan mempengaruhi dampak positif terhadap keberlangsungan pembelajaran yang akan dilakukan sehingga tujuan pembelajaran akan tercapai dengan optimal. Hai ini sesuai dengan pendapat Djamarah (2010:139) "Pengkondisian siswa di awal pembelajaran sebagai bagian dari keterampilan membuka pelajaran sangat penting dilakukan sebagai usaha guru menciptakan prakondisi siswa agar mental maupun perhatiannya terpusat pada materi yang akan dipelajari sehingga memberikan efek positif terhadap kegiatan belajar".

Hal lain yang peneliti lakukan untuk meningkatkan motivasi belajar siswa dengan memberikan pujian dan penghargaan dalam proses belajar. Memberikan pujian dan penghargaan dalam memotivasi siswa untuk semangat mengikuti pelajaran perlu dilakukan karena akan memupuk suasana yang menyenangkan dan mempertinggi gairah dan harga diri siswa. Hal ini sesuai dengan pendapat Sardiman (2011:98) “ Apabila ada siswa yang sukses dan berhasil menyelesaikan tugas dengan baik, perlu diberikan pujian. Pujian ini adalah bentuk reinforcement yang positif dan sekaligus merupakan motivasi yang baik". 
Peningkatan hasil belajar Matematika

Peningkatan hasil belajar ranah kognitif

siswa dalam pembelajaran Matematika melalui model kooperatif tipe TGTdari siklus I sampai

siklus II dapat dilihat pada diagram berikut:

Tabel 2. Data Hasil Belajar Ranah Kognitif SiklusI dan II

\begin{tabular}{lcc}
\hline \multicolumn{1}{c}{ Data hasil belajar } & Siklus I & Siklus II \\
\hline NilaiRata-rata & 68.55 & 77.32 \\
\hline NilaiTerendah & 20 & 50 \\
\hline NilaiTertinggi & 90 & 100 \\
\hline SiswaTuntasBelajar & 15 & 20 \\
\hline SiswaTidakTuntasBelajar & 13 & 8 \\
\hline PersentaseKetuntasan & $54 \%$ & $71 \%$ \\
\hline
\end{tabular}

Berdasarkan tabel di atas, terjadi peningkatan hasil belajar dari siklus I sampai siklus II. Pada Siklus I memperoleh nilai rata-rata kelas 68,55 siswa tuntas belajar dengan persentase ketuntasan $54 \%$. Ketuntasan hasil belajar belum mencapai $70 \%$ sehingga masih perlu dilanjutkan ke siklus II. Sedangkan pada siklus II memperoleh nilai rata-rata kelas 77,32 nilai siswa tuntas belajar dengan persentase ketuntasan $71 \%$. Hal ini menunjukkan penerapan model kooperatif tipe TGT dalam pembelajaran Matematika dapat meningkatkan hasil belajar hingga mencapai ketuntasan klasikal $71 \%$.

Hasil belajar merupakan tolak ukur untuk dapat menilai keberhasilan siswa dalam menguasai materi pembelajaran. Sebagaimana yang dikemukakan Sudjana (dalam Ferdinandus, 2010:3) "hasil belajar adalah kemampuankemampuan yang dimiliki siswa setelah ia menerima pengalaman belajarnya. Berdasarkan pengalaman tersebut seseorang siswa yang telah melakukan kegiatan belajar, akan mampu mengalami perubahan, yaitu adanya kemampuankemampuan yang tadinya tidak ada menjadi ada".

\section{Pembahasan}

Pemaknaan temuan didasarkan hasil observasi, instrumen angket motivasi belajar, tes evaluasi, dan refleksi di akhir pelaksanaan tindakan siklus I dan siklus II mencakup aktivitas siswa, motivasi belajar, dan hasil belajar pada pembelajaran matematika melalui model kooperatif tipe TGT siswa kelas V SDN 04 Kayu Manang Surian.

\section{Motivasi belajar}

Berdasarkan angket motivasi yang telah diberikan setelah menerapkan model kooperatif tipe TGT dalam pembelajaran Matematika motivasi siswa dalam mengikuti pelajaran mengalami peningkatan pada tiap siklusnya. Dari jumlah keseluruhan pernyataan yang telah diajukan, pada siklus I sebanyak 20\% siswa menyatakan sangat setuju dan $51 \%$ menyatakan setuju. Sedangkan pada siklus II sebanyak $46 \%$ siswa menyatakan sangat setuju dan $30 \%$ siswa menyatakan setuju. Peningkatan motivasi siswa pada tiap siklus terjadi karena adanya perbaikan dan pelaksanaan dalam memotivasi siswa seperti memberikan semangat dalam belajar, memberikan penghargaan dan pujian dalam belajar, menggunakan media belajar yang menarik dan menciptakan lingkungan kelas yang bersih, rapi, nyaman, dan menyenangkan dalam belajar.

Adanya hasrat dan keinginan berhasil pada siklus I memperoleh nilai dengan jumlah 11 dengan persentase $10 \%$ untuk pernyataan sangat setuju dan 70 dengan persentase $63 \%$ untuk pernyataan setuju. Sedangkan pada siklus II memperoleh jumlah nilai 49 dengan persentase $44 \%$ untuk pernyataan sangat setuju dan 39 dengan persentase $35 \%$ untuk pernyataan setuju untuk indikator adanya hasrat dan keinginan berhasil. Pada siklus I guru kurang memotivasi dan membangkitkan minat siswa dalam belajar sehingga keinginan untuk belajar, mengerjakan soal yang sulit, semangat belajar walaupun nilai ulangan jelek, dan keinginan untuk bertanya jika ada pelajaran yang belum dimengerti menjadi lebih 
rendah dan kurang. Pada siklus II peneliti mencoba memperbaiki permasahan tersebut dengan membangkitkan minat dan keinginan dalam belajar dengan cara: (1) mengatakan kepada siswa "Ananda, pelajaran itu akan bermanfaat bagi kita dalam kehidupan sehari-hari, dengan rajin belajar dan memahami pelajaran maka kita tidak akan bisa dibodohi oleh orang lain" (2) Mengaitkan materi yang disampaikan dengan permasalahan yang dialami oleh siswa dalam kehidupan sehari-hari (3) memberikan kesempatan dan waktu yang luas bagi siswa yang lambat untuk mendapatkan nilai yang lebih baik. Membangkitkan minat siswa dalam belajar perlu dilakukan karena proses belajar akan berjalan lancar kalau disertai dengan minat dan keinginan yang kuat. Hal ini sesuai dengan pendapat Sardiman (2011:98) "Motivasi muncul karena adanya kebutuhan, begitu juga minat sehingga tepatlah kalau minat merupakan alat motivasi yang pokok. Proses belajar akan berjalan lancaar kalau disertai minat".

Adanya dorongan dan kebutuhan dalam belajar pada siklus I memperoleh nilai dengan jumlah 16 dengan persentase $10 \%$ untuk pernyataan sangat setuju dan 89 dengan persentase $53 \%$ untuk pernyataan setuju. Sedangkan pada siklus II memperoleh jumlah nilai 57 dengan persentase $34 \%$ untuk pernyataan sangat setuju dan 62 dengan persentase $37 \%$ untuk pernyataan setuju untuk indikator adanya dorongan dan kebutuhan dalam belajar. Pada siklus I guru kurang memotivasi siswa agar bersemangat dalam belajar sehingga siswa kurang menyenangi pelajaran dan malas dalam mengerjakan latihan dan PR. Pemberian motivasi penting dilakukan karena akan mempengaruhi keefektifan belajar siswa. Salah satu cara yang dilakukan oleh peneliti pada siklus II untuk memperbaiki permasalahan pada siklus I adalah dengan mengkondisikan kelas dengan baik, peneliti mengecek kesiapan siswa sebelumbelajar secara fisik dan mental karena kesiapan fisik dan mental akan mempengaruhi dampak positif terhadap keberlangsungan pembelajaran yang akan dilakukan sehingga tujuan pembelajaran akan tercapai dengan optimal. Sesuai dengan pendapat Djamarah (2010:139) "Pengkondisian siswa di awal pembelajaran sebagai bagian dari keterampilan membuka pelajaran sangat penting dilakukan sebagai usaha guru menciptakan prakondisi siswa agar mental maupun perhatiannya terpusat pada materi yang akan dipelajari sehingga memberikan efek positif terhadap kegiatan belajar".

Adanya penghargaan dalam belajar pada siklus I memperoleh nilai dengan jumlah 14 dengan persentase $25 \%$ untuk pernyataan sangat setuju dan 34 dengan persentase $61 \%$ untuk pernyataan setuju. Sedangkan pada siklus II memperoleh jumlah nilai 29 dengan persentase $52 \%$ untuk pernyataan sangat setuju dan 19 dengan persentase $34 \%$ untuk pernyataan setuju untuk indikator adanya penghargaan dalam belajar. Pada siklus I guru kurang memotivasi siswa dengan memberikan pujian dan penghargaan selama pembelajaran berlangsung. Sedangkan pada siklus II guru sudah lebih banyak memberikan pujian dengan mengucapkan kata-kata bagus, pintar dan hebat kepada siswa yang sudah mau aktif dalam belajar, menjawab pertanyaan, dan berdiskusi. Memberikan pujian dan penghargaan dalam memotivasi siswa untuk semangat mengikuti pelajaran perlu dilakukan karena akan memupuk suasana yang menyenangkan dan mempertinggi gairah dan harga diri siswa. Hal ini sesuai dengan pendapat Sardiman (2011:98) "Apabila ada siswa yang sukses dan berhasil menyelesaikan tugas dengan baik, perlu diberikan pujian. Pujian ini adalah bentuk reinforcement yang positif dan sekaligus merupakan motivasi yang baik".

Adanya kegiatan yang menarik dalam belajar pada siklus I memperoleh nilai dengan jumlah 13 dengan persentase $15 \%$ untuk pernyataan sangat setuju dan 26 dengan persentase $31 \%$ untuk pernyataan setuju. Sedangkan pada siklus II memperoleh jumlah nilai 25 dengan persentase $30 \%$ untuk pernyataan sangat setuju dan 22 dengan persentase $26 \%$ untuk pernyataan setuju untk indikator adanya kegiatan yang menarik dalam belajar. Pada siklus I guru telah menyediakan media belajar berupa plastik transparan tetapi masih kurang didukung media gambar yang banyak dan menarik sehingga menimbulkan kebosanan bagi siswa selama proses belajar mengajar berlangsung, pada kegiatan presentasi kelompok guru belum memfasilitasi siswa dengan media yang cukup sehingga menyulitkan siswa dalam menyelesaikan soal yang elah diberikan, sehingga pada siklus II diperlukan 
media yang memudahkan siswa dalam menyelesaikan soal. Untuk memotivasi siswa agar lebih senang dan bersemangat dalam belajar pada siklus II peneliti menyediakan papan planel untuk menempelkan media plastik tgransparan didepan kelas kemudian peneliti juga memperbanyak media gambar yang menarik dan bervariasi sehingga membantu siswa menghilangkan kebosanan dalam belajar. Salah satu fungsi media dalam belajar adalah untuk meningkatkan motivasi siswa dalam mempelajari sesuatu dan menimbulkan kegairahan dalam belajar. Fathurrohman dkk, (2010:67) mengemukan "ungsi media dalam proses pembelajaran diantaranya : (1) menarik perhatian siswa (2) membantu mempercepat pemahaman dalam prose belajar (3) memperjelas penyajian pesan agar tidak bersifat verbalistik (4) waktu pembelajaran bisa dikondisikan (5) meningkatkan motivasi siswa dalam mempelajari sesuatu/menimbulkan gairah dalam belajar, dan (10) meningkatkan keaktifan/keterlibatan siswa dalam kegiatan pembelajaran.

Adanya lingkungan belajar yang kodusif pada siklus I memperoleh nilai dengan jumlah 30 dengan persentase $54 \%$ untuk pernyataan sangat setuju dan 23 dengan persentase $41 \%$ untuk pernyataan setuju. Sedangkan pada siklus II memperoleh jumlah nilai 47 dengan persentase $84 \%$ untuk pernyataan sangat setuju dan 6 dengan persentase $11 \%$ untuk pernyataan setuju untk indikator adanya hasrat dan keinginan berhasil. Lingkungan belajar yang kondusif dan nyaman merupakan salah satu daya penggerak yang ada dalam diri seseorang yang dapat menimbulkan kegiatan kegiatan belajar, memberi arah dan menjamin kelangsungan belajar serta berperan dalam hal penumbuhan positif, seperti kegairahan, rasa senang belajar sehingga menambah pengetahuan dan keterampilan. Menurut Sumantri (2015:378) "Seseorang akan termotivasi untuk belajar karena adanya lingkungan yang kondusif, sehingga siswa dapat belajar dengan baik".

\section{Hasil Belajar}

Hasil belajar merupakan tolak ukur untuk dapat menilai keberhasilan siswa dalam menguasai materi pembelajaran. Sebagaimana yang dikemukakan Sudjana (dalam Ferdinandus, 2010:3) "hasil belajar adalah kemampuan-kemampuan yang dimiliki siswa setelah ia menerima pengalaman belajarnya. Berdasarkan pengalaman tersebut seseorang siswa yang telah melakukan kegiatan belajar, akan mampu mengalami perubahan, yaitu adanya kemampuan-kemampuan yang tadinya tidak ada menjadi ada".

Hasil belajar yang harus dimiliki dan dicapai oleh siswa berupa pengetahuan (kognitif), sikap (afektif), dan keterampilan (psikomotor). Hal ini dijelaskan oleh Ahmad (2010:1) yang mengemukakan "Manusia selalu mengalami proses belajar mengajar baik secara formal maupun informal. Dari proses belajar yang dilakukan manusia itu akan diperoleh sebuah hasil belajar. Setelah proses belajar diharapkan terjadi perubahan tingkah laku baik dari dari segi pengetahuan (kognitif), nilai dan sikap (afektif), dan keterampilan (psikomotor). Perubahan-perubahan itu yang dinamakan hasil belajar".

Untuk meningkatkan hasil belajar siswa guru perlu memberikan motivasi kepada siswa selama proses pembelajaran. Hal ini sesuai dengan pendapat Sanjaya (2009:29) yang mengemukakan bahwa "proses pembelajaran akan berhasil manakala siswa mempunyai motivasi dalam belajarnya". Lebih lanjut, Sardiman (2011:84) mengemukakan "hasil belajar akan menjadi optimal, kalau ada motivasi. Makin tepat motivasi yang diberikan akan makin berhasil pula pelajaran itu".

Dari analisis penelitian siklus I dapat diketahui persentase nilai kognitif adalah 54\%, persentase afektif adalah 69\%, dan persentase psikomotor adalah $74,5 \%$. Sedangkan pada siklus II diketahui persentase nilai kognitif adalah $71 \%$, persentase afektif adalah $85 \%$ dan persentase psikomotor adalah 85,5\%. Berdasarkan hasil pengamatan siklus II yang diperoleh maka pelaksanaan siklus II dinyatakan sudah berhasil, dan guru sudah berhasil dalam usaha meningkatkan hasil belajar siswa.

Peningkatan motivasi dan hasil belajar siswa dalam pembelajaran Matematika melalui model kooperatif tipe TGT dipengaruhi oleh ranah afektif dan psikomotorik. Pada awal pelaksanaan tindakan siklus I, suasana kelas belum terkondisikan baik karena siswa belum terbiasa mengikuti pembelajaran menggunakan 
model kooperatif tipe TGT sehingga masih gaduh, kurang termotivasi, kurang semangat. Kegiatan pengamatan serta diskusi dilakukan kurang tertib karena siswa kurang terampil dan bekerja sama menyelesaikan tugas sehingga berpengaruh

\section{SIMPULAN DAN REKOMENDASI}

Penerapan model kooperatif tipe TGT pada pembelajaran Matematika dapat meningkatkan motivasi belajar siswa, pada tiap siklus I persentase dari seluruh pernyataan yang telah di isi siswa memperoleh nilai dengan persentase $20 \%$ menyatakan sangat setuju, $51 \%$ menyatakan setuju. Sedangkan pada siklus II memperoleh nilai dengan persentase $46 \%$ menyatakan sangat setuju, $30 \%$ siswa menyatakan setuju. Penerapan model kooperatif tipe TGT pada pembelajaran matematika dapat meningkatkan hasil belajar matematika siswa kelas V SDN 04 Kayu Manang Surian. Hal ini dapat dilihat pada nilai rata-rata ketuntasan hasil belajar siswa pada siklus I memperoleh nilai rata-rata 68,55 mengalami peningkatan pada siklus II menjadi 77,32 .

Berdasarkan simpulan di atas, dapat penelitit rekomendasikan sebagai berikut:

1. Bagi guru

Model kooperatif tipe TGT hendaknya diterapkan dalam pembelajaran Matematika karena dapat membantu guru mengaitkan materi yang diajarkan dengan situasi nyata dan mendorong siswa membuat hubungan antara

\section{DAFTAR PUSTAKA}

Depdiknas. (2006). Kurikulum Tingkat Satuan Pendidikan. Jakarta: Depdiknas.

Djamarah, S. B. (2010). Guru dan Anak Didik dalam Interaksi Edukatif: Bandung: Rineka Cipta.

Karso, dkk. (2008). Pendidikan Matematika 1. Jakarta: Universitas Terbuka.

Kunandar. (2008). Guru Profesional Implementasi Kurikulum Tingkat Satuan Pendidikan (KTSP) dan Sukses dalam Sertifikasi Guru.Jakarta: PT raja Grafindo Persada. pada nilai tes evaluasinya. Namun setelah dilakukan perbaikan berdasarkan permasalahan di siklus I, hasil belajar siswa ranah kognitif, afektif, maupun psikomotorik mengalami peningkatan di siklus berikutnya.

pengetahuan yang dimiliki dengan kehidupan sehari-hari.

2. Bagi siswa

Model kooperatif tipe TGT sangat baik diterapkan karena dapat menumbuhkan keterampilan interpersonal meliputi: berani bertanya, kerjasama, partisipasi aktif, menghargai pendapat teman, berbagi tugas mengambil giliran, tidak meninggalkan tempat duduk sebelum tugas selesai, bertanggung jawab, serta memberikan pengalaman belajar lebih bermakna bagi siswa karena berinteraksi langsung dengan sumber atau bahan ajar yang dipelajari.

3. Bagi sekolah

Dibutuhkan waktu lebih lama untuk dapat menerapkan pendekatan inovatif dengan benar dalam pembelajaran Model kooperatif tipe TGT karena baik guru maupun siswa perlu waktu berlatih membiasakan diri belajar sesuai sintaks pada mata pelajaran sama maupun di kelas berbeda. Selain itu, melalui penelitian dengan pendekatan inovatifdapat meningkatkan mutu pendidikan khususnya mata pelajaran Matematika.

Makmun, A.S. (2007). Psikologi Kependidikan. Bandung: Remaja Rosdakarya.

Purwanto, N. (2007). Psikologi Pendidikan Remaja. Bandung: Rosdakarya.

Rusman. (2011). Model-Model Pembelajaran Mengembangkan Profesionalisme Guru. Jakarta: PT. Rajagrafindo Persada.

Sardiman, A.M. (2011). Interaksi dan Motivasi Belajar Mengajar. Jakarta: PT Raja Grafindo Persada. 
Suryabrata, S. (2011). Psikologi Pendidikan. Jakarta: PT. Raja Grafindo Persada.

Sobur, A. (2009). Psikologi Umum. Bandung: CV. Pustaka Setia.

Slavin, R.E. (2011). Cooperative Learning Teori, Riset, dan Praktek. Terjemahan: Narulita Yusron. 2011. Bandung: Nusa Media.

Usman, U. (2008). Menjadi Guru Profesional. Bandung: PT Remaja Rosdakarya.

Uno, H.B. (2009). Teori motivasi dan Pengukurannya (Analisis di Bidang Pendidikan). Jakarta : Bumi Aksara.

Wahyuni, D. (2001). Studi Tentang Pembelajaran Kooperatif Terhadap Hasil Belajar Matematika. Malang: Program Sarjana Universitas Negeri Malang. 